\title{
The Relationship between Metacognitive Reading Strategies Use and Reading Comprehension Achievement of EFL Learners
}

\author{
Mina Rastegar, Ehsan Mehrabi Kermani, Massoud Khabir \\ Shahid Bahonar University, Kerman, Iran \\ Email: Massoud.khabir@gmail.com
}

How to cite this paper: Rastegar, M., Mehrabi Kermani, E., \& Khabir, M. (2017). The Relationship between Metacognitive Reading Strategies Use and Reading Comprehension Achievement of EFL Learners. Open Journal of Modern Linguistics, 7, 65-74. https://doi.org/10.4236/ojml.2017.72006

Received: March 3, 2017

Accepted: April 15, 2017

Published: April 18, 2017

Copyright $\odot 2017$ by authors and Scientific Research Publishing Inc. This work is licensed under the Creative Commons Attribution International License (CC BY 4.0).

http://creativecommons.org/licenses/by/4.0/ c) (i) Open Access

\begin{abstract}
The purpose of the present study was to explore the relationship between EFL learners' metacognitive reading strategies use and their reading comprehension achievement. To fulfill this objective, 120 Iranian EFL students studying at Shahid Bahonar University of Kerman and Valiasr University of Rafsanjan took part in this study. The participants were selected from among senior BA students majoring in English Literature and English Translation. In order to obtain the required data, two instruments were utilized: survey of reading strategies by Mokhtari and Sheorey (2002) and a TOEFL reading comprehension test chosen from the materials officially printed by Educational Testing Service (2003). After collecting the required data, the statistical procedures were done using SPSS version 18. The findings of this study revealed that there was a significant positive relationship between the use of overall metacognitive reading strategies by the participants and their reading comprehension achievement.
\end{abstract}

\section{Keywords}

Metacognitive Reading Strategies Use,

Reading Comprehension Achievement EFL Students

\section{Introduction}

In most L2 contexts, the focus of attention is directed towards students' learning. To accomplish learning, the ultimate aim of teaching, nobody can deny the roles of teachers and learners as two of the most influential factors to this end. Teachers' role is essential as they plan and execute their lessons in a way to provide the learners with the input necessary for learning. On the other hand, students or learners' conscious or unconscious adoption of approaches towards learning of 
different L2 tasks, or, in other words, directing and optimizing this input, are of utmost importance.

Reading comprehension as one of the main sources providing the learner with the essential input (Harmer, 2007) plays a very crucial role in L2 learning process. It is one of the skills of language whose mastery is an indication of language achievement which is the ultimate aim of teaching. According to Anderson (1982), Carrell (1998) and Eskey (1973) reading is an essential skill for students, especially for those wanting to attend university. Johnston (1983) puts forth that reading is to build a model of meaning.

Accordingly, with due observance of the significance of reading comprehension in L2 achievement, influential factors in this respect are to be paid attention. In this respect, as emphasized by some researchers, an awareness of reading strategies use helps the learners get the most out of a text (Anderson, 2002; Mokhtari \& Sheorey, 2002; Oxford, 1994). If a learner becomes strategic in reading, comprehension improves. Grabe (2009) mentions that the strategic reader is aware of the effectiveness of his or her comprehension with regard to reading goals and applying sets of appropriate strategies to enhance comprehension of difficult texts.

\section{Metacognitive reading strategies}

Among different classifications putting forward for metacognitive reading strategies, the category fitting the present study is the model proposed by Mokhtari and Sheorey (2002). The main reason to administer this scale is best stated by Mokhtari and Sheorey (2002). They state that it is particularly designed to measure metacognitive reading strategies of L2 learners while reading academic materials. In their model, the survey of reading strategies, including 30 items, three sub categories are recognized: global reading strategies, problem solving reading strategies and support reading strategies.

The use of global reading strategies is directed towards a global analysis of the reading text. For example, paying attention to the characteristics of the text, guessing what the text is about, and the like. Use of these strategies helps the reader make himself or herself ready to comprehend the main text. These strategies are mostly general and intentionally employed. This category contains 13 items.

The name of problem solving strategies is suggestive in itself. These strategies help the reader tackle the problem while the text becomes difficult to understand. Examples include re-reading for a better understanding, pausing and thinking about the text, starting again from the part where you lost your concentration, and so forth. These strategies help the readers in the real act of reading a text, allowing the reader to get through the text skillfully. This category contains 8 items.

Support reading strategies mostly involve using outside reference materials, taking notes, underlining information, and other practical strategies. Via these support or functional strategies, a reader can sustain responses to the reading text. This category includes 9 items. 


\section{Reading comprehension}

Reading comprehension is generally defined as a process by which meaning is constructed through coordinating a number of complex processes such as reading of words, knowledge of words, text organization, strategies and even knowledge of the world (Cain, Oakhill, \& Bryant, 2004; Fuchs, Fuchs, Hosp, \& Jenkins, 2001; Paris, Carpenter, Paris, \& Hamilton, 2005; Paris, Wasik, \& Turner, 1991; Perfetti \& Hogaboam, 1975). In the current study the views of Anderson (2003) toward reading comprehension are adopted. He considers reading as a fluent process gone through by readers. In this process learners combine information from the text with their own background knowledge mutually bottom-up and top-down to construct meaning. Here comprehension is defined as the goal of reading. Consequently, Anderson's views toward reading comprehension best apply to the sample of this study.

\section{Literature Review}

Barnett (1988) conducted a study concerning second language reading on French language students, and the results indicated that the proficient readers showed more awareness of their use of metacognitive reading strategies in reading comprehension compared to the less proficient readers. Chern (1993) demonstrated that there was a positive relationship between readers' metacognitive reading strategy awareness and their reading comprehension process in EFL/ESL. Also, the findings of a research carried out in Japan on Japanese ESL students showed that ESL students having high levels of English proficiency used more metacognitive reading strategies (Upton, 1997).

Moreover, Sheorey and Mokhtari (2001) found a correlation between high proficiency students and the high frequency use of these strategies. Wen (2003) also indicated that most of the comprehension activities of effective readers happened at the level of meta-cognition. Congruent with the above, Wang et al. (2009) found that those learners who could use metacognitive reading strategies were more successful in their reading and learning program. In line with the results of the previous study, Senay Sen (2009) found a statistically significant relationship between reading comprehension achievement scores and meta-cogni tive reading strategies use.

Furthermore, Takallou (2011) indicated that the two experimental groups which received instruction on planning and self-monitoring performed much better than the control group in the reading comprehension test. Ahmadi, Ismail and Abdullah (2013) also contended that more successful readers used metacognitive reading strategy in their reading comprehension more than the less successful readers.

The significant positive relationship between Metacognitive Strategy Use and Englisg reading comprehension was also illustrated in a study undertaken by Zhang and Seepho (2013).

Although the above mentioned studies have validated the relationship between metacognitive reading strategy use and reading comprehension achieve- 
ment, the current study tried to shed more light on this relationship by conducting the replication in a novel new setting in Iran.

\section{Research Questions}

The research question is as follows:

Is there any statistically significant relationship between EFL learners' overall metacognitive reading strategies use and reading compression achievement?

\section{Methodology}

\section{Participants}

The participants of this study were 120 male and female senior BA students of English majoring in literature and translation in Shahid Bahonor University of Kerman and Valiasr University of Rafsanjan, aged between 21 and 24. To choose the participants, available sampling technique was employed. Accordingly, in this procedure all the available members of the population had an equal and independent chance of being included in the sample (Ary, Jacob, \& Razavieh, 1972).

The rationale behind choosing senior students of English was that students at this level were supposed to have higher levels of proficiency. Based on the syllabus of English major in our context, these senior students all had passed the grammar, reading comprehension and writing courses, so all these might justify the proficiency level of these students in English. Furthermore, senior students of English at this level seemingly had had more exposure to L2 reading through their course of their studies. Accordingly, the participants were perceived to comprehend the items of the questionnaires very well and to have more experience in dealing with reading tasks.

\section{Instruments}

In order to obtain data on the variables two questionnaires were administered.

1) The 30-item Survey of Reading Strategies (SORS), developed by Mokhtari and Sheorey (2002), was employed to measure the type and frequency of the participants' MRS use.

2) TOEFLPBT reading comprehension test.

SORS was developed by Mokhtari and Sheorey (2002). It consists of 30 items each of which is answered in a 5-point Likert scale. Based on the application of the strategy mentioned by each item, they range from 1, always or almost always, to 5 , never or almost never. It consists of three subscales: global reading strategies, 13 items; problem solving reading strategies, 8 items; and support reading strategies, 9 items. The minimum and maximum possible scores for overall metacognitive reading strategies are 30 and 150, respectively. Moreover, minimum and maximum possible scores for global, problem solving and support reading strategies are $13-65,8-40$, and $9-45$, respectively. It is to mention that the higher the score, the higher the use of the strategies (Mokhtari \& Sheorey, 2002).

This instrument was field tested and validated by Sheorey and Mokhtari (2001) on a population of L2 students studying at 2 of the United Stated of 
America universities, and based on the consistency of the results, the internal reliability equaled 0.89 or better. This indicates a reasonable degree of consistency to measure awareness and perceived use of reading strategies among non-native speakers of English.

The main reason to administer this scale is best stated by Mokhtari and Sheorey (2002). They state that it is particularly designed to measure metacognitive awareness of reading strategies of L2 learners while reading academic materials.It is however based on the Metacognitive Awareness of Reading Strategies Inventory (MARSI) (Mokhtari \& Reichard, 2002), which was basically designed to measure this awareness among adult native speakers of English while reading school-based or academic texts.

Furthermore, the SORS has been widely administered in both ESL and EFL settings such as Hungary (Sheorey \& Baboczky, 2008), Japan (Sheorey, Kamimura, \& Freirmuth, 2008), Bahrain (Malcolm, 2009), Iran (Kamran \& Maftoon, 2012) and China (Pei, 2014).

The 50-item reading comprehension test was adopted from the TOEFL Paper-Based testing materials developed by Educational Testing Service (2003), the only authority in the world in charge of constructing TOEFL tests. This test includes five passages each being around 25 lines. Each passage is followed by several questions about it. For questions 1 - 50, the participants were to choose the one best answer (A), (B), (C), or (D), to each question. Then, on their answer sheet, they found the number of the question and filled in the space that corresponded to the letter of the answer they had chosen.

The reason underlying such a choice is that TOEFL and International English Language Testing System (IELTS) tests are the only general proficiency tests which are accepted worldwide by the top universities of the world. Success in either of the tests, as required by the universities, is the best proof for general English proficiency of non-native students of English who are going to attend the universities where the language of instruction is English.

\section{Data Collection Procedure}

The data were collected in the spring semester of the academic year 2014-2015 in the abovementioned universities. After getting the instructors' agreement, the researcher attended the classes and gave a brief explanation concerning the variables and also the importance of the study. In order to avoid any possible negative effect, the participants were asked not to write their names on the questionnaires for the sake of confidentiality. They were also told that there would not be any wrong or right answers to any of the items in the scales.

SORS questionnaire was distributed which took around 30 minutes. After that the 50-item reading comprehension test was distributed, and the participants were asked to choose the best answer to each item and mark it on the answer sheet. SORS questionnaires were held in hand by the participants until the end of the reading test. The standard allocated time for this part, as recommended by ETS, was 55 minutes. Finally, the two instruments belonging to each participant stapled together were collected. 


\section{Data Analysis Procedure}

After the required data were collected, the obtained data were assessed using SPSS (Version 18). To answer each major and minor question, a Pearson Product-Moment Correlation Coefficient was conducted to seek any significant relations between variables. It is worth mentioning that no participant was excluded from the study as they had attended all the items and apparently no carelessness had been observed by the researcher.

\section{The Formulation of the Study}

This study was a descriptive quantitative research as the findings were based on the responses given by the participants. It was also a correlational study as it attempted to find the correlation between the variables.

This study was conducted cross-sectionally, i.e., at a specific time at ShahidBahonar University of Karman and Valiasr University of Rafsanjan. Moreover, since the researcher had no control over the manipulation of the variables, the design of the study was ex post facto.

\section{Results}

\section{Descriptive Statistics of the Variables}

The descriptive statistics of the variables have been presented in Table 1.

As shown in Table 1, there were 120 participants in this research. The two variables, namely overall metacognitive reading strategies and reading comprehension achievement, were measured by SORS scale and a 50-item reading comprehension ETSTOEFL test, respectively. Overall metacognitive reading strategies use scores were extracted carefully and mentioned descriptively here as well as the scores for reading comprehension achievement.

Overall Metacognitive Reading Strategies Use in Relation with Reading

\section{Comprehension Achievement}

In order to investigate the research question regarding the relationship between overall metacognitive reading strategies use and reading comprehension achievement, a Pearson Product-Moment Correlation Coefficient was conducted. The results of this statistical test are presented in Table 2 .

The analysis of the data shows that Pearson correlation coefficient between overall metacognitive reading strategies use and reading comprehension achievement is 0.65 with the $\mathrm{P}$-value of 0.00 which is less than the significant level of $\alpha=0.05$. Therefore, it can be concluded that there is a significant positive relationship between overall metacognitive reading strategies use and read-

Table 1. The descriptive statistics of the variables.

\begin{tabular}{cccccccc}
\hline & N & Range & Min & Max & Mean & SD & Variance \\
\hline OMRS & 120 & 74.00 & 55.00 & 129.00 & 108.89 & 16.48 & 271.89 \\
RCA & 120 & 39.00 & 10.00 & 49.00 & 38.30 & 10.49 & 110.14 \\
Valid N (listwise) & 120 & & & & & & \\
\hline
\end{tabular}

Note: OMRS $=$ Overall Metacognitive Reading Strategies Use; RCA = Reading Comprehension Achievement. 
Table 2. Overall Metacognitive reading strategies use in relation with reading comprehension achievement.

\begin{tabular}{cccc}
\hline & & OMRS & RCA \\
\hline \multirow{2}{*}{ OMRS } & Pearson Correlation & 1 & $0.65^{* *}$ \\
& Sig.(2-tailed) & & 0.00 \\
& $\mathrm{~N}$ & 120 & 120 \\
& Pearson Correlation & $0.65^{* *}$ & 1 \\
& Sig.(2-tailed) & 0.00 & 120 \\
\hline
\end{tabular}

${ }^{*}$ Correlation is significant at the 0.01 level (2-tailed). Note: OMRS $=$ Overall Metacognitive Reading Strategies Use; RCA $=$ Reading Comprehension Achievement.

ing comprehension achievement (Table 2).

\section{Discussion}

Regarding the research question of this study, it was revealed that the relationship between overall metacognitive reading strategies use and reading comprehension achievement was significant and positive. In line with this finding, the study done by Barnett (1988) on French language students indicated that the proficient readers showed more awareness of their use of metacognitive reading strategies in reading comprehension compared to the less proficient readers. Chern (1993) also demonstrated that there was a positive relationship between readers' metacognitive reading strategy awareness and their reading comprehension processes in EFL/ESL. Wen's (2003) study also supports the current study finding by saying that most of the comprehension activities of effective readers happened at the level of metacognition.

Furthermore, the results of a study conducted on university EFL students by Wang et al. (2009) in China revealed other benefits of metacognitive reading strategies on reading comprehension. In this study, those learners who could use metacognitive reading strategies such as planning, monitoring and evaluating were more successful in their reading and learning program compared to those who did not utilize these strategies (Wang et al., 2009). In line with the results of the previous study, Senay Sen (2009) found a statistically significant relationship between reading comprehension achievement scores and metacognitive reading strategies use. The work undertaken by Takallou (2011) also indicated the effectiveness of metacognition in relation with reading.

In two other studies, some significant positive correlations between metacognitive strategy use and reading comprehension were again intensified (Ahmadi, Ismail, \& Abdullah, 2013; Zhang \& Seepho, 2013).

\section{Limitations and Directions for Further Studies}

During the course of research, the researcher faced some limitations. First, it was a hard work to have all the participants take part in the research and answer 
both the scale and the ETSTOEFL test which are relatively long. Second, the scores obtained from SORS scale are self reported; consequently, people may evade revealing themselves as honestly as expected. There are also a bunch of other factors namely, personality and affective factors, which may prevent the participant to reflect their true self.

Therefore, it is recommended for other researchers to conduct replications of the current study in a longitudinal design investigating all other possible factors such as personality styles, culture, goal achievement orientations as well as other ones affecting the use of metacognitive reading strategies and reading comprehension achievement.

\section{Conclusion}

All in all, the significant role of reading comprehension as a valuable source for provision of input in an L2 context should be thoughtfully taken into consideration. And also the use of metacognitive reading strategies by learners towards the optimal learning of this input and final application of it are recommended. It seems making L2 learners strategic in reading comprehension yields better learning outcomes.

\section{References}

Ahmadi, M. R., Ismail, H. N., \& Abdullah, M. K. K. (2013). The Importance of Metacognitive Reading Strategy Awareness in Reading Comprehension. English Language Teaching, 6, 235-244.

Anderson, N. J. (2002). The Role of Metacognition in Second/Foreign Language Teaching and Learning. ERIC Digest. Washington DC: ERIC Clearinghouse on Languages and Linguistics.

Anderson, N. J. (2003). Teaching Reading. In D. Nunan (Ed.), Practical English Language Teaching (pp. 67-86). New York: McGraw-Hill Publishers.

Anderson, O. S. (1982). Comprehension of College Age Students: The State of the Art. Reading World, 21, 213-225. https://doi.org/10.1080/19388078209557648

Ary, D., Jacob, L. C., \& Razavieh, A. (1972). Introduction to Research in Education. New York: Holt, Rinehart, and Winston.

Barnett, M. A. (1988). Reading through Context: How Real and Perceived Strategies Use Affects L2 Comprehension. Modern Language Journal, 72, 150-162. https://doi.org/10.1111/j.1540-4781.1988.tb04177.x

Cain, K., Oakhill, J., \& Bryant, P. (2004). Children's Reading Comprehension Ability: Concurrent Prediction by Working Memory, Verbal Ability, and Component Skills. Journal of Educational Psychology, 96, 31-42. https://doi.org/10.1037/0022-0663.96.1.31

Carrell, P. L. (1998). Can Reading Strategies Be Successfully Taught? Australian Review of Applied Linguistics, 21, 1-20. https://doi.org/10.1075/aral.21.1.01car

Chern, C. L. (1993). Chinese Students' Word-Solving Strategies in Reading in English. In T. Huckin, M. Haynes, \& C. Coady (Eds.), Second Language Reading and Vocabulary Learning (pp. 67-85). Norwood, NJ: Ablex.

Eskey, D. E. (1973). A Model Program for Teaching Advanced Reading to Students of English as a Foreign Language. Language Learning, 23, 169-184. 


\section{https://doi.org/10.1111/j.1467-1770.1973.tb00653.x}

Fuchs, L. S., Fuchs, D., Hosp, M. K., \& Jenkins, J. R. (2001). Oral Reading Fluency as an Indicator of Reading Competence: A Theoretical, Empirical, and Historical Analysis. Scientific Studies of Reading, 5, 239-256. https://doi.org/10.1207/S1532799XSSR0503 3

Grabe, W. (2009). Reading in a Second Language: Moving from Theory to Practice. Cambridge: Cambridge University Press.

Harmer, J. (2007). The Practice of English Language Teaching (4th ed.). England: Pearson Education.

Johnston, P. H. (1983). Reading Comprehension Assessment: A Cognitive Basis. Newark, NJ: International Reading Association.

Kamran, S. K., \& Maftoon, P. (2012). An Analysis of the Associations between Ambiguity Tolerance and EFL Reading Strategy Awareness. English Language Teaching, 5, 188-196.

Malcolm, D. (2009). Reading Strategy Awareness of Arabic-Speaking Medical Students Studying in English. System, 37, 640-651.

Mokhtari, K., \& Reichard, C. (2002). Assessing Students' Metacognitive Awareness of Reading Skills. Journal of Educational Psychology, 94, 249-259.

https://doi.org/10.1037/0022-0663.94.2.249

Mokhtari, K., \& Sheorey, R. (2002). Measuring ESL Students' Awareness of Reading Strategies. Journal of Developmental Education, 25, 2-11.

Oxford, R. L. (1994). Language Learning Strategies: An Update. www.cal.org/resources/digest/oxford01.html

Paris, S. G., Carpenter, R. D., Paris, A. H., \& Hamilton, E. E. (2005). Spurious and Genuine Correlates of Children's Reading Comprehension. In S. G. Paris, \& S. A. Stahl (Eds.), Children's Reading Comprehension and Assessment (pp. 131-160). Mahwah, NJ: Lawrence Erlbaum Associates Publishers.

Paris, S. G., Wasik, B. A., \& Turner, J. C. (1991). The Development of Strategies of Readers. In R. Barr, M. Kamil, P. Mosenthal, \& P. D. Pearson (Eds.), Handbook of Reading Research (Vol. 2, pp. 609-640). Mahwah, NJ: Lawrence Erlbaum Associates.

Pei, L. (2014). Does Metacognitive Strategy Instruction Indeed Improve Chinese EFL Learners' Reading Comprehension Performance and Metacognitive Awareness? Journal of Language Teaching and Research, 5, 1147-1152. https://doi.org/10.4304/jltr.5.5.1147-1152

Perfetti, C. A., \& Hogaboam, T. (1975). Relationship between Single Word Decoding and Reading Comprehension Skill. Journal of Educational Psychology, 67, 461-469. https://doi.org/10.1037/h0077013

Senay Sen, H. (2009). The Relationship between the Use of Metacognitive Strategies and Reading Comprehension. Procedia Social and Behavioral Sciences, 1, 2301-2305.

Sheorey, R., \& Baboczky, E. S. (2008). Metacognitive Awareness of Reading Strategies among Hungarian College Students. In K. Mokhtari, \& R. Sheorey (Eds.), Reading Strategies of First- and Second-Language Learners: See How They Read (pp. 161-173). Norwood, MA: Christopher-Gordon Publishers.

Sheorey, R., \& Mokhtari, K. (2001). Differences in the Cognitive Awareness of Reading Strategies among Native and Non-Native Readers. System, 29, 431-449.

Sheorey, R., Kamimura, Y., \& Freirmuth, M. R. (2008). Reading Strategies of the Users of English as a Library Language: The Case of Japanese ESP Students. In K. Mokhtari, \& R. Sheorey (Eds.), Reading Strategies of First- and Second-Language Learners: See How They Read (pp. 175-184). Norwood, MA: Christopher-Gordon Publishers. 
Takallou, F. (2011). The Effect of Metacognitive Strategy Instruction on EFL Learners' Reading Comprehension Performance and Metacognitive Awareness. Asian EFL Journal, 12, 272-300.

Upton, T. A. (1997). First and Second Language Use in Reading Comprehension Strategies of Japanese ESL Students. Teaching English as a Second Language Electronic Journal, 3, 1-27. http://tesl-ej.org/ej09/a3.html

Wang, J., Spencer, K., Minjie, \& Xing, M. (2009). Metacognitive Beliefs and Strategies in Learning Chinese as a Foreign Language. System, 37, 46-56.

Wen, Q. F. (2003). A Successful Road to English Learning. Shanghai: Shanghai Foreign Language Education Press.

Zhang, L., \& Seepho, S. (2013). Metacognitive Strategy Use and Academic Reading Achievement: Insights from a Chinese Context. Electronic Journal of Foreign Languages Teaching, 10, 54-69.

Submit or recommend next manuscript to SCIRP and we will provide best service for you:

Accepting pre-submission inquiries through Email, Facebook, LinkedIn, Twitter, etc. A wide selection of journals (inclusive of 9 subjects, more than 200 journals)

Providing 24-hour high-quality service

User-friendly online submission system

Fair and swift peer-review system

Efficient typesetting and proofreading procedure

Display of the result of downloads and visits, as well as the number of cited articles

Maximum dissemination of your research work

Submit your manuscript at: http://papersubmission.scirp.org/

Or contact ojml@scirp.org 